\title{
EFEKTIVITAS BANK SENTRAL DALAM MENJAGA KESTABILAN NILAI TUKAR
}

\author{
Kevin $^{1}{ }^{*}$, Eva Sentiani Situngkir ${ }^{1}$, Eka Solid Diana ${ }^{1}$, Raihan Tenrigangka ${ }^{1}$, \\ Ayu Rosa Syaputri ${ }^{1}$, Dini Hartanti ${ }^{1}$, Achmad Kurniadi ${ }^{1}$ \\ ${ }^{1}$ Universitas Bangka Belitung \\ * Email: kevinnandez8@gmail.com
}

\begin{abstract}
ABSTRAK: Jurnal ini mengidentifikasi efektivitas bank sentral dalam menjaga kestabilan nilai tukar. Adapun variabel yang diambil untuk diteliti adalah suku bunga dalam negeri, suku bunga luar negeri, pertumbuhan ekonomi dan inflasi. Dengan menggunakan metode analisis regresi linear berganda, jurnal ini menemukan bahwa suku bunga dalam negeri dan suku bunga luar negeri berpengaruh signifikan terhadap nilai tukar. Ketika suku bunga dalam negeri naik sebesar satu persen maka nilai tukar akan meningkat sebesar enam persen yang artinya rupiah akan melemah terhadap dollar. Namun, peneliti juga menemukan bahwa suku bunga luar negeri berpengaruh negatif terhadap nilai tukar. Sedangkan pertumbuhan ekonomi dan inflasi tidak berpengaruh terhadap nilai tukar.
\end{abstract}

Kata Kunci: Nilai Tukar; Suku Bunga; Pertumbuhan Ekonomi; Inflasi

\section{PENDAHULUAN}

\subsection{Latar Belakang}

Fluktuasi nilai tukar Rupiah selalu menarik untuk diikuti. Nilai tukar rupiah akan mempengaruhi tingkat inflasi suatu negara. Inflasi merupakan salah satu faktor yang membuat nilai tukar selalu berubah-ubah. Negara yang inflasinya rendah atau stabil, nilai mata uangnya jarang sekali mengalami pelemahan terhadap mata uang lain. Berbeda dengan negara yang inflasinya lebih sering naik ketimbang turunnya, nilai mata uangnya lebih sering melemah dan sewaktu-waktu menguat (tidak stabil).Perubahan tingkat inflasi dan nilai tukar Rupiah dipengaruhi oleh berbagai faktor dalam perekonomian suatu negara, salah satunya dipengaruhi oleh operasi moneter sebagai pelaksanaan kebijakan moneter oleh Bank Indonesia, selaku Bank Sentral Indonesia.

Sebagai otoritas moneter, perbankan dan sistem pembayaran, tugas utama Bank Indonesia tidak saja menjaga stabilitas moneter, namun juga stabilitas sistem keuangan (perbankan dan sistem pembayaran). Keberhasilan Bank Indonesia dalam menjaga stabilitas moneter tanpa diikuti oleh stabilitas sistem keuangan, tidak akan banyak artinya dalam mendukung pertumbuhan ekonomi yang berkelanjutan. Stabilitas moneter dan stabilitas keuangan ibarat dua sisi mata uang yang tidak dapat dipisahkan. Kebijakan moneter memiliki dampak yang signifikan terhadap stabilitas keuangan begitu pula sebaliknya, stabilitas keuangan merupakan pilar yang mendasari efektivitas kebijakan moneter. Sistem keuangan merupakan salah satu alur transmisi kebijakan moneter, sehingga bila terjadi ketidakstabilan sistem keuangan maka transmisi kebijakan moneter tidak dapat berjalan secara normal. 
Sebaliknya, ketidakstabilan moneter secara fundamental akan mempengaruhi stabilitas sistem keuangan akibat tidak efektifnya fungsi sistem keuangan.

Bank Indonesia menetapkan kebijakan moneter, memiliki hak dan kewajiban untuk mengatur kondisi tingkat inflasi dan stabilitas nilai tukar Rupiah harus berada pada level aman agar dapat menjaga stabilitas perekonominan dalam Negeri tetap dalam kondisi stabil.

Krisis disebabkan oleh kebijakan yang dibuat oleh bank sentral, yang justru cenderung mempertahankan tingkat bunga yang terlalu rendah dapat memicu terjadinya krisis, sebagaimana konsekuensi dari rendahnya inflasi dalam jangka waktu yang cukup panjang. (Taylor, 2009).

Berdasarkan peran dan fungsi dari Bank Indonesia, kinerja Bank Indonesia sangat dituntut untuk dapat menjaga kestabilan nilai tukar Rupiah dan tingkat inflasi. Perbaikan masalah inflasi di Indonesia, tidak dapat dilakukan hanya dengan menggunakan instrumeninstrumen moneter, tetapi juga harus melakukan perbaikan pada sektor riil, yaitu dengan sasaran utama nya yaitu meminimalisir hambatan-hambatan struktural yang ada dalam perekonomian nasional. (Atmadja, 2004).

\subsection{Rumusan Masalah}

Nilai tukar rupiah terhadap dolar saat ini sedang mahal dan cenderung tidak stabil. Permasalahannya, Bank Indonesia sebagai bank sentral harus mampu mengeluarkan kebijakan-kebijakan yang efektif demi menjaga kestabilan nilai tukar rupiah agar tidak menyebabkan krisis.

\subsection{Tujuan Penelitian}

Adapun tujuan penelitian ini adalah mengetahui kebijakan moneter apa saja yang Bank Indonesia lakukan dalam upaya menstabilkan nilai tukar Rupiah terhadap Dolar AS dan mengetahui kinerja Bank Indonesia dan pencapaiannya pada pelaksanaan kebijakan moneter, yaitu mengendalikan tingkat inflasi dan menstabilkan nilai tukar Rupiah terhadap Dolar AS.

\section{TINJAUAN PUSTAKA}

\subsection{Landasan Teori}

\subsubsection{Pengertian Kebijakan Moneter}

Adalah suatu kebijakan otoritas Bank Sentral dalam upaya mengendalikan tingkatmoneter untuk mencapai perkembangan kegiatan pereknomian yang diinginkan. (Santoso, 2003).

Kebijakan moneter merupakan suatu proses mengatur cadangan uang suatu negara,seperti meminimalisir tingkat inflasi dan meningkatkan kesejahteraan Negara. (Yustika \& Erani, 2010) dalam kaitannya dengan tujuan mencapai stabilitas ekonomi, kebijakanmoneter bersifat dinamis dan selalu disesuaikan dengan kebutuhan negara tersebut. Strategi kebijakan yang diterapkan tiap-tiap negara berbeda antara satu dengan lainnya,yaitu disesuaikan dengan tujuan dan juga mekanisme transmisi yang berlaku pada perekonomian negara tersebut.

\subsubsection{Pengertian Nilai Tukar Rupiah}

Nilai tukar atau kurs merupakan harga mata uang suatu negara terhadap mata uang negara lain yang dapat dibeli dan dijual.Triyono (2008) mengutarakan bahwa kurs (exchange rate) adalah pertukaran antara dua mata uang yang berbeda, yaitu merupakan perbandingan nilai atau harga antara kedua mata uang tersebut. Kurs menunjukan berapa nilai rupiah yang harus dibayarkan untuk satuan mata uang asing, dan berapa nilai rupiah yang harus dibayar 
ketika seseorang menjual mata uang asing. Kurs mata uang menunjukkan harga mata uang apabila ditukarkan dengan mata uang lain. Penentuan nilai kurs mata uang suatu negara dengan mata uang negara lain ditentukan oleh permintaan dan penawaran mata uang yang bersangkutan. Berdasarkan pendapat ahli di atas dapat disimpulkan bahwa pengertian kurs (exchange rate) merupakan harga suatu mata uang terhadap mata uang lain, sehingga kurs rupiah terhadap dollar Amerika Serikat dapat diartikan harga mata uang rupiah terhadap dolar Amerika Serikat. Putong (2013) menjelaskan bahwa berdasarkan perkembangannya, sistem penetapan kurs mata uang dikelompokan sebagai berikut :

a. Sistem Kurs Tetap (Fixed Exchange Rate) Sistem kurs tetap baik yang disetarakan oleh suatu lembaga keuangan internasional (IMF), maupun oleh masing-masing negara sesuai dengan kemampuan ekonomisnya (biasanya berdasarkan nilai dari Hard Currency)yaitu sistem kurs yang mematok nilai kurs mata uang asing terhadap mata uang negara yang bersangkutan dengan nilai tertentu yang selalu sama dalam satu periode.

b. Sistem Kurs Mengambang (Floating Exchange Rate - FER)yaitu nilai mata uang suatu negara ditentukan oleh kekuatan permintaan dan penawaran pada pasar uang (resmi).

c. Sistem Kurs Terkait (Pagged Exchange Rate - PER) Sistem kurs yang dikaitkan dengan nilai mata uang negara lain, atau sejumlah mata uang tertentu. Bila kedua sistem nilai kurs yang telah dijelaskan di atas adalah nilai kurs tertinggi terakhir, maka sistem PER menggunakan nilai kurs tengah mata uang tertentu yang mensyaratkan lebih atau kurang dari kurs tengah sebesar 2,5 persen.

\subsubsection{Pengertian Inflasi}

Inflasi merupakan kenaikan harga-harga barang (secara umum) yang disebabkan oleh turunnya nilai mata uang pada suatu periode tertentu. (Noripin, 2009) mendefinisikan inflasi sebagai proses kenaikan harga-harga barang secara umum dan menyeluruh secara terusmenerus.

Kenaikan harga-harga yang terjadi hanya diwaktu tertentu atau tidak konstant tidak dapat dikatakan sebagai terjadinya inflasi. Inflasi merupakan suatu keadaan dimana tingkat harga secara umum mengalami kenaikan secara terusmenerus.

Terdapat beberapa indikator makro ekonomi yang dapat digunakna dalam menghitung inflasi adalah sebagai berikut (Dornbusch \& Fischer, 1997) :

1. Indeks Harga Konsumen (IHK)

IHK adalah angka indeks yang erhitungan IHK ini berdasarkan harga barang dan jasa yang dikonsumsi oleh masyarakat.

2. Indeks Harga Perdagangan Besar

Berbeda dengan IHK yang menghitung inflasi dari segi konsumen, indeks ini melihat inflasi dari segi produsen. Hal tersebut dapat dilihat dari beberapa tingkat produksi.

3. Indeks Harga Implisit

Perhitungan inflasi dengan IHK dan IHPB memiliki keterbatasan dalam perhitungan. Keterbatasan terdapat hanya pada beberapa orang dibeberapa kota saja, sehingga masih banyak barang-barang yang tidak dimasukan dalam perhitungan menggunakan dua metode tersebut. Untuk itu mendapatkan gambaran inflasi secara lebih luas atau skala yang lebih besar maka para ekonom menggunakan indeks harga implisit.

\subsubsection{Pengertian Suku Bunga}

Menurut Hubbard (1997), bunga adalah biaya yang harus dibayar borrower atas pinjaman yang diterima dan imbalan bagi lender atas investasinya. Sementara itu, Kern dan Guttman (1992) menganggap suku bunga merupakan sebuah harga dan sebagaimana harga 
lainnya, maka tingkat suku bunga ditentukan oleh kekuatan permintaan dan penawaran.

Menurut Karl dan Fair (2001), suku bunga adalah pembayaran bunga tahunan dari suatu pinjaman, dalam bentuk persentase dari pinjaman yang diperoleh dari jumlah bunga yang diterima tiap tahun dibagi dengan jumlah pinjaman. Pengertian suku bunga menurut Sunariyah (2004) adalah harga dari pinjaman. Suku bunga dinyatakan sebagai persentase uang pokok per unit waktu. Bunga merupakan suatu ukuran harga sumber daya yang digunakan oleh debitur yang harus dibayarkan kepada kreditur. Menurut Lipsey, Ragan, dan Courant (1997) suku bunga adalah harga yang dibayarkan untuk satuan mata uang yang dipinjam pada periode waktu tertentu.

Para ekonom membedakan suku bunga menjadi suku bunga nominal dan suku bunga riil. Suku bunga nominal adalah rate yang terjadi di pasar sedangkan suku bunga riil adalah konsep yang mengukur tingkat kembalian setelah dikurangi dengan inflasi. Efek ekspektasi inflasi terhadap suku bunga nominal sering disebut efek Fisher dan hubungan antara inflasi dengan suku bunga ditunjukkan dengan persamaan Fisher.

Laju inflasi sangat penting dalam meramalkan dan menganalisa suku bunga. Selisih antara suku bunga nominal dan inflasi adalah ukuran yang sangat penting mengenai beban sesungguhnya dari biaya suku bunga yang dihadapi individu dan perusahaan. Selain itu, suku bunga riil juga menjadi ukuran yang sangat penting bagi otoritas moneter.

\subsubsection{Suku Bunga LIBOR}

Suku bunga London Inter Bank Offered Rate (LIBOR) merupakan suku bunga internasional yang digunakan sebagai suku bunga padanan antarbank di negara yang berbeda. Suku bunga ini memiliki jangka waktu 1, 3, 6 bulan dan 1 tahun. Pergerakan suku bunga ini sesuai dengan pergerakan pasar uang yang mengikuti kondisi ekonomi dunia. LIBOR merupakan suku bunga yang digunakan oleh bank-bank di dunia, jika jenis surat berharga atau jenis tabungan yang digunakan didominasi oleh mata uang asing atau dalam bentuk US\$. Suku bunga yang diberikan atas jenis tabungan atau surat berharga ini, juga akan diukur sesuai dengan pergerakan nilai US\$.

Di Indonesia, perkembangan suku bunga di dalam negeri selain dipengaruhi oleh laju inflasi, juga dipengaruhi oleh suku bunga internasional. Penurunan dan peningakatan suku bunga di dalam negeri ini sejalan dengan kebijakan Bank Indonesia untuk mengupayakan perbedaan selisih antara tingkat suku bunga domestik dengan suku bunga internasional berada pada tingkat yang wajar, guna mengurangi ekspansi moneter yang berasal dari aliran modal masuk, terutama yang berjangka pendek.

Mobilitas arus modal luar negeri di Indonesia pada dasarnya selain didorong oleh tingginya keterbukaan perekonomian Indonesia, juga sangat terkait dengan besarnya tingkat kepercayaan investor terhadap kondisi fundamental perekonomian dan perbedaan suku bunga dalam negeri (interest rate) yang cukup tinggi.

\subsubsection{Pertumbuhan Ekonomi}

Pertumbuhan ekonomi merupakan sumber utama dalam upayameningkatkan standar hidup masyarakat. Nanga (2005) mendefinisikan pertumbuhan ekonomi adalah peningkatan kemampuan dari suatu perekonomian dalam memproduksi barang dan jasa. Pertumbuhan ekonomi lebih menunjukkan pada perubahan yang bersifat kuantitatif (quantitative change) dan biasanya diukur dengan menggunakan data produk domestik bruto (GDP) atau pendapatan per kapita. 


\subsection{Kerangka Konseptual}

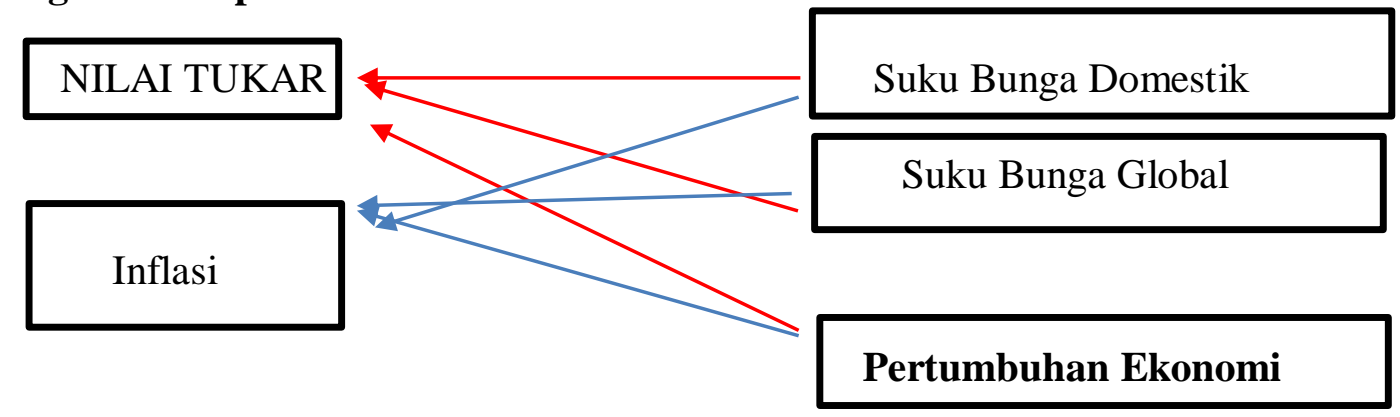

\subsubsection{Hubungan Suku Bunga Domestik dan Suku Bunga Global}

Dengan pendekatan IS-LM, turunnya suku bunga luar negeri akan menyebabkan para investor asing tertarik untuk membeli aset di luar negeri. Untuk dapat berinvestasi, mereka harus membeli mata uang asing. Akibatnya permintaan terhadap mata uang asing meningkat yang akan menguatkan nilai tukar. Penguatan nilai tukar akan menurunkan ekspor neto sehingga kurva IS bergeser ke kiri.

Sebaliknya, dengan meningkatnya suku bunga luar negeri, akan membuat investor domestik membawa uangnya ke luar negeri. Arus keluar modal akan melemahkan nilai tukar. Selanjutnya hal ini akan memperbaiki ekspor netto dan meningkatkan output sehingga kurva IS bergeser ke kanan dan suku bunga meningkat (Raharja dan Manurung, 2008).

\subsubsection{Hubungan Suku Bunga dan Nilai Tukar}

Tingkat suku bunga menentukan nilai tambah mata uang suatu negara. Semakin tinggi suku bunga suatu mata uang, akan semakin tinggi pula permintaan akan uang negara tersebut. Tingkat suku bunga diatur oleh bank sentral, dan jika dalam jangka panjang bank sentral selalu menaikkan suku bunga maka trend nilai tukar uang negara tersebut terhadap negara lain akan cenderung naik. Hal ini akan terus berlangsung sampai ada faktor lain yang mempengaruhi atau bank sentral kembali menurunkan suku bunga.

\subsubsection{Hubungan Pertumbuhan Ekonomi dan Nilai Tukar}

Nanga dalam Roshinta (2014) mengungkapkan bahwa salah satu wujud pembangunan ekonomi suatu negara adalah dengan melakukan hubungan luar negeri, hal ini terwujud dalam perdagangan internasional yang melibatkan negara-negara di dunia. Perdagangan internasional menimbulkan suatu masalah bagi negara pengimpor maupun pengekspor yakni perbedaan nilai mata uang yang digunakan oleh negara-negara tersebut.Hal ini didukung dengan penelitian yang dilakukan oleh Roshinta (2014) yang menyatakan bahwa pertumbuhan ekonomi secara simultan berpengaruh signifikan terhadap nilai tukar Rupiah. Ulfia dan Aliasudin (2011) juga mengatakan bahwa nilai tukar rupiah secara simultan mendapatkan tekanan dari pertumbuhan ekonomi.

\subsubsection{Hubungan Suku Bunga dan Inflasi}

Inflasi dan suku bunga saling berkaitan, hal ini sering diungkapkan dalam teori ekonomi makro. Inflasi merujuk pada tingkat kenaikan harga barang dan jasa. Sementara suku bunga di Indonesia merujuk pada tingkat suku bunga yang diatur oleh Bank Indonesia, dikenal sebagai BI Rate atau suku bunga BI.

Ketika suku bunga rendah, pengaruh yang timbul adalah makin banyak orang meminjam uang. Akibatnya konsumsi bertambah karena jumlah uang beredar lebih banyak, ekonomi mulai tumbuh, dan efek lanjutannya adalah inflasi naik. Dampak sebaliknya juga berlaku, jika suku bunga tinggi, peminjam uang makin sedikit. Hasilnya lebih banyak orang 
menahan belanja, dan memilih menabung. Yang terjadi tingkat konsumsi turun, inflasi pun turun.

\subsubsection{Hubungan Pertumbuhan Ekonomi dan Inflasi}

Hubungan inflasi dan perekonomian menurut Maqrobi (2011), dalam suatu perekonomian, hubungan antara inflasi dengan pertumbuhan ekonomi saling berhubung terbalik. Dengan meningkatnya tingkat inflasi dapat menyebabkan pertumbuhan ekonomi melambat, sebaliknya, inflasi yang relatif rendah dan stabil akan mendorong pertumbuhan ekonomi.

\subsubsection{Hubungan Inflasi dan Nilai Tukar}

Menurut Madura dalam Roshinta (2014) perubahan dalam laju inflasi dapat mempengaruhi aktifitas perdagangan internasional. Jika inflasi suatu negara meningkat, permintaan atas mata uang negara tersebut menurun dikarenakan ekspornya juga turun (disebabkan harga yang lebih tinggi). Selain itu, konsumen dan perusahaan dalam negara tersebut cenderung meningkatkan impor mereka. Kedua hal tersebut akan menekan inflasi yang tinggi pada mata uang suatu negara. Tingkat inflasi antarnegara berbeda, sehingga pola perdagangan internasional dan nilai tukar akan berubah sesuai dengan inflasi tersebut. Selain itu, Keown et.al (2010) menerangkan bahwa hubungan antara tingkat inflasi dengan nilai tukar dapat didukung oleh teori Purchasing Power Parity (PPP). Berdasarkan perubahan jangka panjang dalam nilai tukar tukar dipengaruhi berbagai perbedaan internasional dalam tingkat inflasi dan daya beli mata uang suatu negara. Nilai tukar negara-negara dengan tingkat inflasi yang tinggi cenderung turun. Menurut teori Purchasing Power Parity (PPP), dalam jangka panjang, nilai tukar akan mengalami penyesuaian sehingga daya beli sehingga daya beli setiap mata uang cenderung sama. Maka, perubahan nilai tukar cenderung mencerminkan perbedaan internasional tingkat inflasi.

\subsection{Penelitian Terdahulu}

Tia Ichwani, dkk (2017) menganalisis kebijakan moneter apa saja yang telah diterapkan oleh Bank Indonesia dalam upaya mengendalikan inflasi dan nilai tukar Rupiah terhadap Dollar AS dalam periode tahun 2012 - 2016, serta dampak-dampak kebijakan tersebut bagi kredit UMKM.Hasil yang didapat bahwa kenaikan inflasi selama tahun 2012 2016 secara umum disebabkan oleh bergejolaknya harga-harga pada hampir semua sektor industri dan kenaikan harga BBM. Meskipun demikian, jumlah peminat kredit UMKM tidaklah menurun. Hal ini dapat terlihat dari jumlah dana kredit yang dikucurkan oleh BI selalu mengalami peningkatan pada periode tersebut.

Rytia dan Nyoman (2018) meneliti tentang analisis dampak kebijakan moneter berupa giro wajib minimum terhadap jumlah uang beredar, cadangan devisa, dan laju inflasi di Indonesia. Hasil analisis data menunjukkan giro wajib minimum berpengaruh positif terhadap laju inflasi, BI rate berpengaruhsecarapositif terhadaplajuinflasi, kurs berpengaruh secara negatif terhadap laju inflasi di Indonesia. Pengaruh tidak langsung menunjukkan bahwa giro wajib minimum dan BI rate tidak berpengaruh terhadap laju inflasimelaluijumlah uangberedar, kurs berpengaruh terhadap laju inflasi melalui jumlah uang beredar, sedangkan BI rate dan kurs berpengaruh terhadap laju inflasi melalui cadangan devisa.

Siswadi Sululing (2014) meneliti tentang Peran Bank Indonesia Dalam Menjaga Kestabilan Rupiah. Kebijakan-kebijakan yang dilakukan untuk menstabilkan rupiah yang terdiri dari perbaikan neraca transaksi perjalanan, menjaga nilai tukar dan pemberian insentif, menjaga daya beli masyarakat, serta menjaga tingkat inflasi. 


\section{METODE PENELITIAN}

\subsection{Jenis Penelitian}

Dalam penelitian ini, metode yang digunakan adalah metode kuantitatif, yaitu teknik mengumpulkan, mengolah, menyederhanakan, menganalisis serta menyajikan data kuantitatifagar dapat memberikan data yang teratur tentang suatu peristiwa. Tujuan dari penelitian ini adalah untuk membuat suatu gambaran secara sistematis faktual dan akrual mengenai fakta-fakta realitinya, sifat serta hubungan antara fenomena yang sudah diselidiki.

\subsection{Jenis Data dan Sumber Data}

Jenis data yang digunakan adalah data runtun waktu (time series) periode tahun 2006 sampai tahun 2015. Sumber data yang digunakan oleh penulis berasal dari data sekunder, yaitu data yang telah diolah lebih lanjut dan disajikan baik melalui pihak pengumpul data primer atau oleh pihak lain. Data ini dapat diperoleh dari sumber-sumber tertulis yang terdapat dalam buku yang terkait dengan penelitian ataupun laporan keuangan yang telah dipublikasikan oleh pihak terkait di internet.

\subsection{Metode Pengumpulan Data}

Metode pengumpulan data yang digunakan dalam penelitian ini adalah dengan menggunakan metode pengumpulan data observasi non partisipan. Observasi non partisipan adalah teknik pengumpulan data dengan observasi/pengamatan dimana peneliti tidak terlibat langsung dan hanya sebagai pengamat independen (Sugiyono, 2012). Adapun data yang dikumpulkan melalui proses mempelajari dokumen-dokumen sesuai dengan variabel-variabel dalam model penelitian ini periode 2006-2015.

\subsection{Model Estimasi}

Metode analisis data yang akan digunakan dalam penelitian ini adalah model regresi berganda. Analisis regresi adalah studi ketergantungan dari variabel dependen pada satu atau lebih variabel lain, yaitu variabel independen. Penelitian ini menggunakan analisis berganda dengan data runtun waktu (time series). Analisis data yang dilakukan dengan bantuan Uji Statistik dengan tujuan untuk melihat pengaruh variabel-variabel independen terhadap variabel dependennya.

1. Nilai Tukar

$$
N T=\beta_{0}+\beta_{1} S B D N+\beta_{2} S B L N+\beta_{3} I n f l+\beta_{4} P E+e
$$

Ket:

$$
\begin{array}{ll}
N T & =\text { Nilai Tukar } \\
S B D N & =\text { Suku Bunga Dalam Negeri } \\
\text { SBLN } & =\text { Suku Bunga Luar Negeri } \\
\text { Infl } & =\text { Inflasi } \\
P E & =\text { Pertumbuhan Ekonomi } \\
e & =\text { Error }
\end{array}
$$

2. Inflasi

$$
\text { Inflasi }=\beta_{0}+\beta_{1} S B D N+\beta_{2} S B L N+\beta_{3} P E+\beta_{4} N T+e
$$

Ket:

$$
\begin{aligned}
& S B D N=\text { Suku Bunga Dalam Negeri } \\
& S B L N=\text { Suku Bunga Luar Negeri } \\
& P E \quad=\text { Pertumbuhan Ekonomi } \\
& N T=\text { Nilai Tukar }
\end{aligned}
$$




\subsection{Hipotesis Penelitian}

Hipotesis penelitian ini menjelaskan dugaan sementara terhadap variabel-variabel efektivitas bank sentral yang mempengaruhi kestabilan nilai tukar Rupiah.

H0 = Variabel Suku Bunga Dalam Negeri, Suku Bunga Luar Negeri, Pertumbuhan Ekonomi, dan Inflasi tidak memiliki pengaruh terhadap Nilai Tukar.

H1 = Variabel Suku Bunga Dalam Negeri, Suku Bunga Luar Negeri, Pertumbuhan Ekonomi, dan Inflasi memiliki pengaruh terhadap Nilai Tukar.

\subsection{Definisi Operasional Variabel}

Variabel dependen adalah variabel yang dipengaruhi atau menjadi akibat, karena adanya variabel bebas. Dalam penelitian ini, yang menjadi variabel dependen/terikat adalah Nilai Tukar (Y). Nilai tukar yang dimaksud dalam penelitian ini adalah data nilai tukar rupiah per 1 US\$ pada periode triwulan 2006-2015.

Variabel independen adalah variabel yang mempengaruhi atau yang menjadi penyebab perubahan atau timbulnya variabel terikat. Variabel independen/bebas dalam penelitian ini adalah Suku Bunga Dalam Negeri (X1) yang dinyatakan dalam persentase hasil olah data dari Bank Indonesia, Suku Bunga Luar Negeri (X2) yang juga dinyatakan dalam persentase hasil olah data dari LIBOR, Pertumbuhan Ekonomi (X4) dalam persentase yang diperoleh dari data BPS Indonesia, dan Inflasi (X5) dalam bentuk persentase yang bersumber dari BPS Indonesia.

\section{HASIL DAN PEMBAHASAN}

Analisis regresi adalah suatu analisis yang digunakan untuk mengukur pengaruh variabel bebas terhadap variabel terikat. Jika pengukuran pengaruh ini melibatkan dua atau lebih variabel bebas $(\mathrm{X})$ dan variabel terikat $(\mathrm{Y})$ maka dinamakan analisis regresi linear berganda.

Ada beberapa hasil regresi yang akan dijelaskan pada penelitian ini. Ada dua pendekatan yang dilakukan untuk melihat hubungan antara kestabilan nilai tukar dengan efektivitas bank sentral.

- Model Nilai Tukar

Berikut hasil pengolahan data model 1.

$$
N T=8.92+0.063 S B D N-0.058 S B L N-0.011 \text { Infl }-0.005 P E+e
$$

Perhatikan tabel hasil regresi berikut.

Tabel 4.1. Hasil Regresi Model Nilai Tukar

\begin{tabular}{cccc}
\hline Variabel & Koefisien & $\mathrm{T}_{\text {hitung }}$ & $\mathrm{P}>|t|$ \\
\hline Konstanta & 8.91529 & 59.78 & 0.000 \\
SBDN & 0.0630364 & 2.18 & 0.036 \\
SBLN & -0.0579955 & -3.73 & 0,001 \\
PE & -0.0054241 & -0.65 & 0.518 \\
Inflasi & -0.011358 & -0.97 & 0.340 \\
Adj R & 0.2305 & & \\
Number of obs & 40 & & \\
Prob>F & 0.0098 & & \\
R-squared & 0.3094 & & \\
\hline
\end{tabular}

Sumber: STATA data diolah (2019) 
Dari hasil analisis data, diketahui bahwa model regresi bernilai signifikan dan terdapat beberapa variabel yang bisa mempengaruhi nilai tukar.

Perhatikan grafik berikut.

Diagram Koefisien Model Nilai Tukar

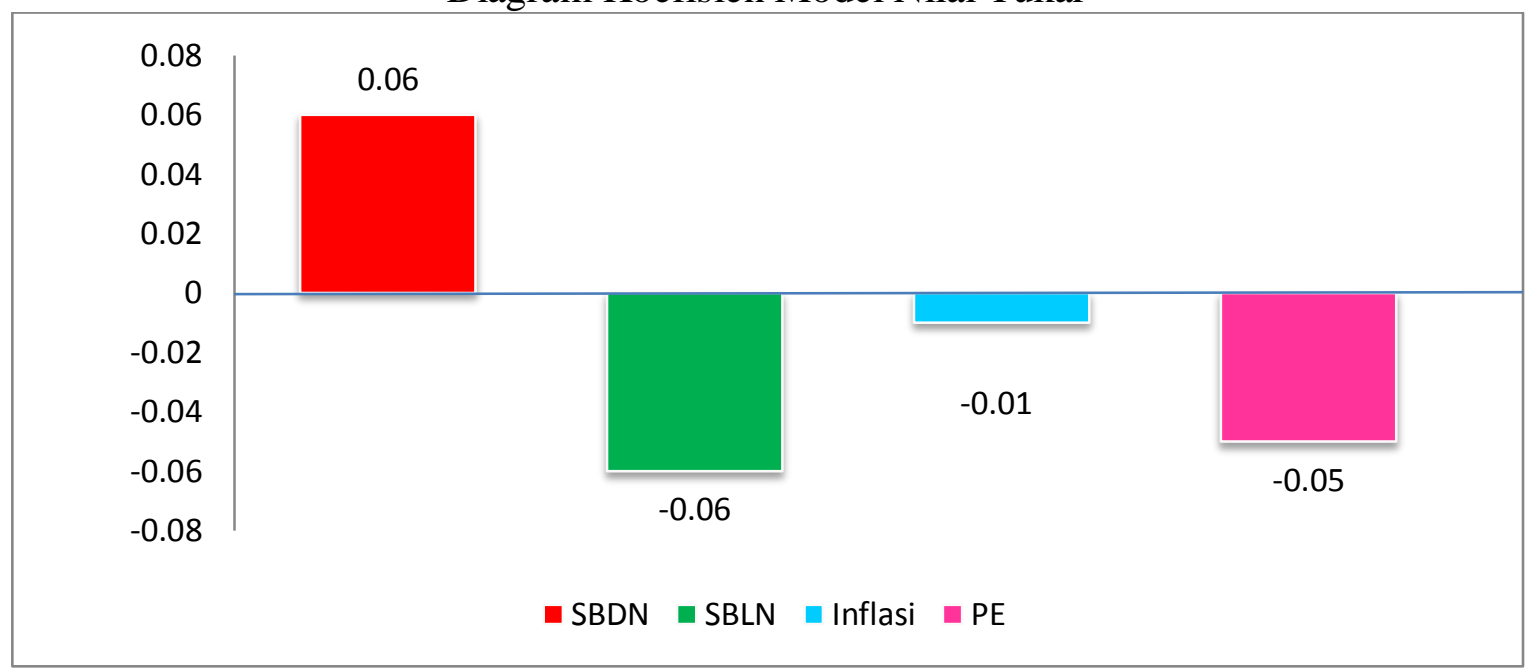

Hasil regresi menunjukkan bahwa nilai konstanta sebesar 8.91529 yang menyatakan bahwa jika variabel independen dianggap konstan, maka nilai tukar akan terdepresiasi dengan sendirinya sebesar 8.9 persen.

Suku bunga dalam negeri memberikan pengaruh terhadap nilai tukar. Hasil regresi menunjukkan bahwa jika suku bunga dalam negeri meningkat 1 persen, maka akan meningkatkan nilai tukar dan menyebabkan nilai tukar terdepresiasisebesar 6,3 persen.

Selanjutnya suku bunga luar negeri memberikan pengaruh yang negatif terhadap nilai tukar. Hasil regresi menunjukkan bahwa jika suku bunga luar negeri meningkat sebesar1 persen maka nilai tukar akan menurun sebesar 5,8 persen.

Pertumbuhan ekonomi memiliki $\mathrm{p}>|\mathrm{t}|$ sebesar 0,518 dan inflasi memiliki $\mathrm{p}>|\mathrm{t}|$ sebesar 0,34 yang artinya berada diatas 0,05 (standar eror). Itu menunjukkan bahwa pertumbuhan ekonomi dan inflasi tidak berpengaruh signifikan terhadap nilai tukar.

Berdasarkan uji koefisien determinasi, variabel independen dapat menjelaskan variabel dependen sebesar 30 persen. Artinya pengaruh Suku Bunga Dalam Negeri, Suku Bunga Luar Negeri, Inflasi, dan Pertumbuhan Ekonomi terhadap Nilai Tukar adalah sebesar 30 persen. Sedangkan 70 persen dijelaskan oleh variabel lain di luar model penelitian ini.

\section{- Model Inflasi}

Berikut hasil pengolahan data model 2.

$$
\text { Inflasi }=12.68+2.09 S B D N-0.57 S B L N+0.15 P E-2.29 N T+e
$$

Perhatikan tabel hasil regresi berikut 
Tabel 4.2. Hasil Regresi Model Inflasi

\begin{tabular}{cccc}
\hline Variabel & Koefisien & $\mathbf{T}_{\text {hitung }}$ & $\mathbf{p}>|\boldsymbol{t}|$ \\
\hline Konstanta & 12.68252 & 0.59 & 0.558 \\
SBDN & 2.092905 & 8.07 & 0.000 \\
SBLN & -0.5784851 & -2.39 & 0.022 \\
PE & 0.1520738 & 1.31 & 0.198 \\
Nilai Tukar & -2.294405 & -0.97 & 0.340 \\
Adj R & 0.7288 & & \\
Number of obs & 40 & & \\
Prob>F & 0 & & \\
R-squared & 0.7567 & & \\
\end{tabular}

Sumber: STATA data diolah (2019)

Dari hasil analisis data, diketahui bahwa model regresi bernilai signifikan dan terdapat beberapa variabel yang bisa mempengaruhi inflasi.

Perhatikan grafik berikut.

Diagram Koefisien Model Inflasi

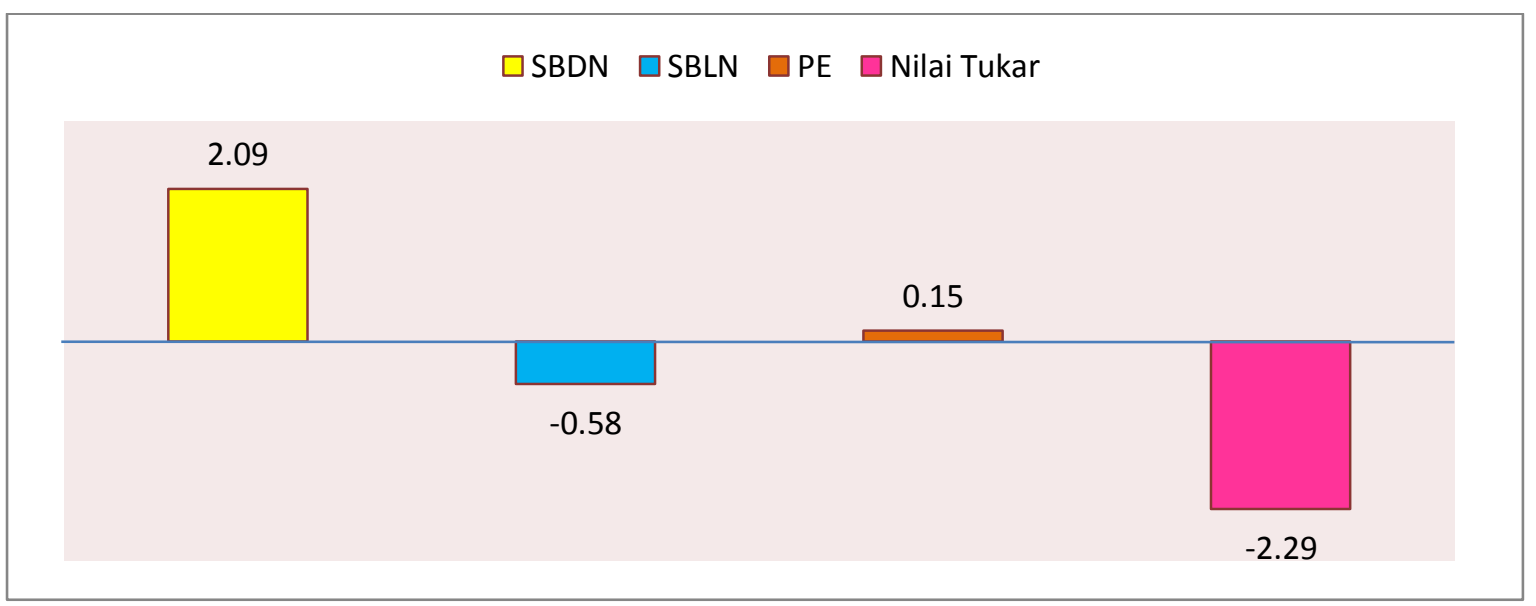

Hasil regresi menunjukkan bahwa nilai konstanta sebesar 12,68252 yang menyatakan bahwa jika variabel independen dianggap konstan, maka inflasi akan meningkat sebesar 12,68 persen.

Suku bunga dalam negeri memberikan pengaruh terhadap inflasi. Hasil regresi menunjukkan bahwa jika suku bunga dalam negeri meningkat 1 persen, maka akan meningkatkan inflasisebesar 2,09 persen.

Selanjutnya suku bunga luar negeri memberikan pengaruh yang negatif terhadap inflasi. Hasil regresi menunjukkan bahwa jika suku bunga luar negeri meningkat sebesar1 persen maka inflasi akan menurun sebesar 0,58 persen.

Pertumbuhan ekonomi memiliki $\mathrm{p}>|\mathrm{t}|$ sebesar 0,198 dan nilai tukar memiliki $\mathrm{p}>|\mathrm{t}|$ sebesar 0,34 yang artinya berada diatas 0,05 (standar eror). Itu menunjukkan bahwa pertumbuhan ekonomi dan nilai tukar tidak berpengaruh signifikan terhadap inflasi.

Berdasarkan uji koefisien determinasi, variabel independen dapat menjelaskan variabel dependen sebesar 75 persen. Artinya pengaruh Suku Bunga Dalam Negeri, Suku 
Bunga Luar Negeri, Inflasi, dan Pertumbuhan Ekonomi terhadap Nilai Tukar adalah sebesar 75 persen. Sedangkan 25 persen dijelaskan oleh variabel lain di luar model penelitian ini.

\section{KESIMPULAN}

Informasi utama yang hendak digali pada penelitian ini adalah dugaan mengenai efektivitas bank sentral dalam menjaga kestabilan nilai tukar. Hasil menunjukkan bahwa suku bunga dalam negeri dan suku bunga luar negeri mempengaruhi nilai tukar, sedangkan inflasi dan pertumbuhan ekonomi tidak berpengaruh terhadap nilai tukar. Pada model kedua ditemukan bahwa suku bunga dalam negeri dan suku bunga luar negeri mempengaruhi inflasi, sedangkan pertumbuhan ekonomi dan nilai tukar tidak mempengaruhi inflasi.

Dalam penelitian ini ditemukan bahwa untuk menjaga kestabilan nilai tukar, bank sentral dapat mengeluarkan kebijakan moneter dalam bentuk penentuan suku bunga. Hal ini karena variabel suku bunga dalam negeri dan suku bunga luar negeri berpengaruh signifikan terhadap nilai tukar.

Temuan menarik lainnya adalah bahwa tingkat inflasi tidak mempengaruhi nilai tukar, begitupun sebaliknya nilai tukar tidak mempengaruhi inflasi. Inflasi dan nilai tukar hanya dipengaruhi oleh suku bunga dalam negeri dan suku bunga luar negeri.

\section{UCAPAN TERIMAKASIH}

Penulis mengucapkan terimakasih yang sebesar-besarnya kepada bapak M. Faisal Akbar, S.E., M.S.E selaku dosen pembimbing dalam penyusunan jurnal ini dan juga kepada teman-teman kelompok 2 yang terdiri dari kevin, eva, eka, raihan, ayu rosa, dini dan ahmad yang telah bekerja keras dalam penyusunan penelitian ini sehingga dapat selesai dengan baik.

\section{DAFTAR PUSTAKA}

Ichwani, Tia., dkk. (2017). "Analisis Kinerja Bank Indonesia Sebagai Stabilitator Inflasi Dan Kurs Rupiah Di Bidang Moneter". Journal of Applied Business and Economics Vol. 4 No. 3 250-265.

Mardiana, Riva., dkk. (2016). "Pengaruh Tingkat Inflasi Dan Pertumbuhan Ekonomi Terhadap Nilai Tukar Rupiah (Studi Pada Bank Indonesia Periode Tahun 2005 2014)". e-Proceeding of Management : Vol.3, No.2 Page 1691.

Fauji, Diah Ayu Septi. (2016). "Faktor - Faktor Yang Mempengaruhi Nilai Tukar Rupiah Periode 2013 - Triwulan I 2015".

Simorangkir, Iskandar., Suseno. (2002). "Sistem dan Kebijakan Nilai Tukar". Pusat Pendidikan Dan Studi Kebanksentralan (Ppsk) Bank Indonesia.

Sululing, Siswadi. (2014). "Peran Bank IndonesiaDalam Menjaga Kestabilan Rupiah". Fakultas Ekonomi Universitas Muhammadiyah Luwuk.

Hartini, Dwi., Utomo, Yuni Prihadi. (2004). "Analisis Pengaruh Inflasi Terhadap Pertumbuhan Ekonomi di Indonesia dengan Metode Final Prediction Error". Jurnal Ekonomi Pembangunan Vol. 5, No.1, hal. 42-49.

Nugroho, Hariyatmoko Nurcahyo. (2010). "Pengaruh Kebijakan BI Rate Terhadap Suku Bunga Kredit Investasi Bank Umum Periode Juli 2005 - Desember 2009”. Fakultas Ekonomi Program Magister Perencanaan dan Kebijakan Publik Jakarta 